\title{
Adenocarcinoma of the small intestine complicating Crohn's disease
}

\author{
P C HAWKER, S N GYDE, H THOMPSON, AND R N ALLAN \\ From the Gastroenterology Unit, The General Hospital, Birmingham
}

SUMMARY Adenocarcinoma of the small intestine is an uncommon complication of Crohn's disease. We report the clinical and pathological details of three cases diagnosed between 1968 and 1980 with a review of 58 cases from the literature. Of the 61 cases, 41 tumours occurred in the ileum, 18 in the jejunum, one in the duodenum and ileum, and one in the ileum and colon. Eighteen occurred in bypassed intestinal loops. The prognosis was poor: 44 patients $(72 \%)$ had died with a mean interval of only 7.9 months from the diagnosis of cancer.

Adenocarcinoma of the small bowel complicating Crohn's disease was first described by Ginzburg et al. ${ }^{1}$ in 1956. We have traced 58 examples of this association in the literature, the majority having been described as individual case reports. Individual case reports suggest an association between Crohn's disease and cancer, but neither of the two statistical studies of the cancer risk in Crohn's disease has shown an increased risk of cancer developing in the small intestine. ${ }^{2}{ }^{3} \mathrm{We}$ report three cases diagnosed in this unit between 1968 and 1980 with a review of the literature.

\section{Case reports}

CASE 1

R W, a man, was born on 11 January 1944 . He presented at 14 years of age with abdominal pain and general malaise. Barium follow-through examination was reported as normal. Two years later when he was first seen in this unit a barium follow-through examination showed Crohns's disease of the ileum. He was treated with sulphasalazine and corticosteroids. An extensive jejunoileitis was found at laparotomy in 1964. No resection or bypass was performed. He was treated by vagotomy and pyloroplasty for duodenal ulcer in 1967 when Crohn's disease of the small intestine was still present, but the appearances had improved since 1964 . At laparotomy in 1968 for subacute intestinal obstruction extensive malignant deposits were found throughout the peritoneum, pelvis, and liver. The resected small intestinal specimen showed multiple strictures and sacculation with superficial ulceration and fissures,

Received for publication 17 August 1981 mucosal oedema, and fibrosis. There was an ulcerated lesion $(3 \times 2 \mathrm{~cm}) 3 \mathrm{~cm}$ from the distal end of the resected specimen. Histological examination showed

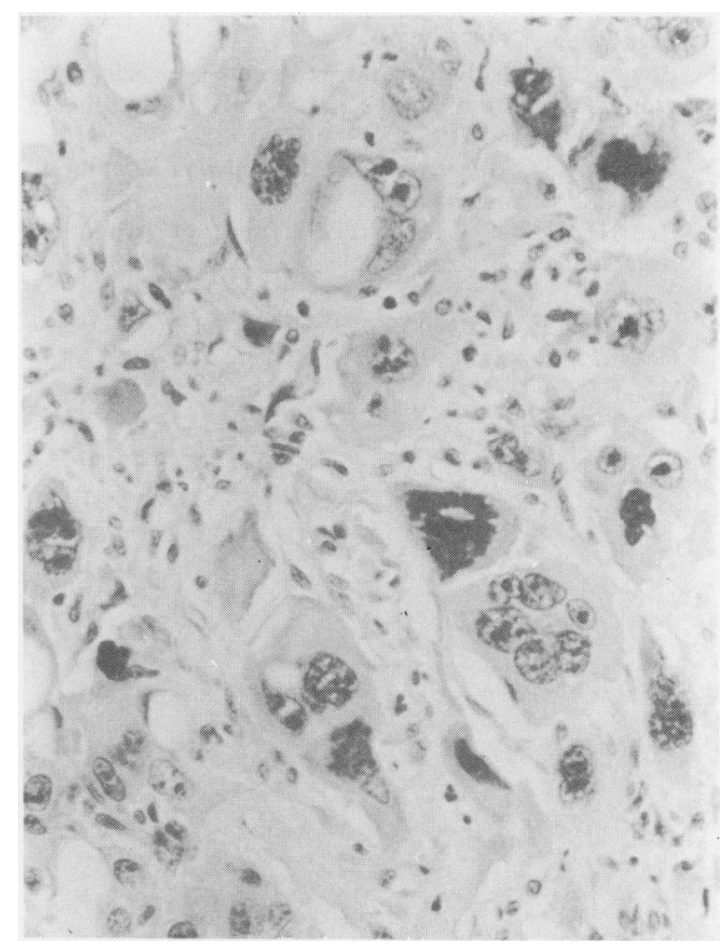

Fig. 1 Case 1. Histology showing anaplastic carcinoma. Haematoxylin and eosin. 
an anaplastic carcinoma with signet ring cells (Fig. 1) extending through all layers to the peritoneal surface. He died in October 1968.

\section{CASE 2}

C P, a man, was born on 9 September 1924. He presented in 1969 with recurrent episodes of colicky abdominal pain and diarrhoea. Barium follow-through examination showed Crohn's disease of the terminal ileum. He refused surgical treatment and was lost to follow-up. He was readmitted as an emergency in 1979 with obstructive symptoms and a large tender mass in the right iliac fossa. At laparotomy a large abscess was found complicating extensive terminal ileal Crohn's disease with strictures and local enteroenteric fistulae. The abscess was drained and the macroscopic Crohn's disease was resected. The resected specimen showed extensive hose-pipe thickening and ulceration with lymphoid hyperplasia, micro-abscesses, oedema, fibrosis and one giant cell follicle, characteristic of Crohn's disease. Histological examination of the ulcerated lesion showed a moderately well-differentiated mucus-secreting adenocarcinoma extending through all layers of the ileal wall (Fig. 2). There was also evidence of mucosal dysplastic change. He died postoperatively of a massive pulmonary embolus.

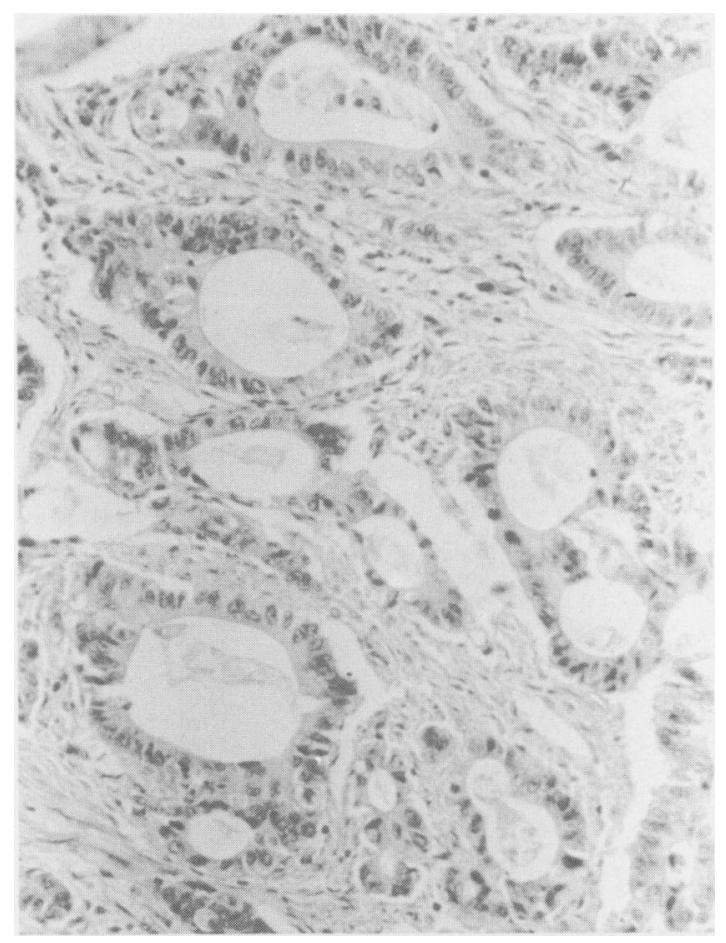

Fig. 2 Case 2. Histology showing mucus-secreting adenocarcinoma. Haematoxylin and eosin.
CASE 3

M R, a woman, was born on 8 January 1929 . She presented in 1962 with anorexia, malaise, and loss of weight. At laparotomy there were a few enlarged soft mesenteric lymph nodes, but no other abnormality. Histological examination of the lymph nodes showed reactive hyperplasia only. A recent review of this material showed no evidence of Crohn's disease. She remained well until 1974 when she presented with general malaise, loss of weight, and vomiting. Barium follow-through examination showed multiple jejunal strictures but her symptoms resolved without specific treatment. In October 1980 she was first seen in this unit with a recurrence of her symptoms. At laparotomy there was evidence of Crohn's disease extending for some $90 \mathrm{~cm}$ from the duodenojejunal junction with multiple skip lesions in the distal jejunum. The proximal jejunal segment was resected. The resected specimen showed multiple strictures with ulceration, oedema, fibrosis, lymphoid hyperplasia, and giant cell follicles. A small carcinoma of the jejunum was found on careful inspection of the resected specimen. Histological examination showed a small papillary adenocarcinoma penetrating the muscularis propria (Fig. 3a). The adjacent mucosa showed severe dysplasia and an in-situ intramucosal carcinoma (Fig. 3b).

\section{Review of literature}

The published reports of 58 cases of carcinoma of the small intestine complicating Crohn's disease and the present series (61 cases in all) are summarised in Table 1. The case mentioned by Lear ${ }^{47}$ and the two cases described by Marshak, cited by Floch et al. ${ }^{43}$ have been excluded because there was insufficient clinical detail. We have also excluded one of the cases described by Farmer $e t a l .^{21}$ as it was not clear whether the tumour arose in the small or large intestine. Greenstein et ll $^{48}$ recently reviewed their experience of cancer in inflammatory bowel disease and considered four cases of cancer complicating small intestinal Crohn's disease. These cases have been reported earlier by them and are included in this review under Greenstein et al. ${ }^{42}$ The reported cases of carcinoid tumour of the small bowel have also been excluded.

A summary of the available elinical information is shown in Table 2. The mean interval between the diagnosis of Crohn's disease and cancer was 18.2 years (range one week to 47 years). The mean age at diagnosis of cancer was 46.9 years (range $20-80$ years). The cancers occurred predominantly in the ileum (41 cases); of the remainder, 18 cases occurred in the jejunum, one in the duodenum and ileum, and one in the ileum and colon. Eighteen cancers occurred in bypassed intestinal loops. The reported survival is shown in Table 2. 
Table 1 Summary of literature review-clinical information

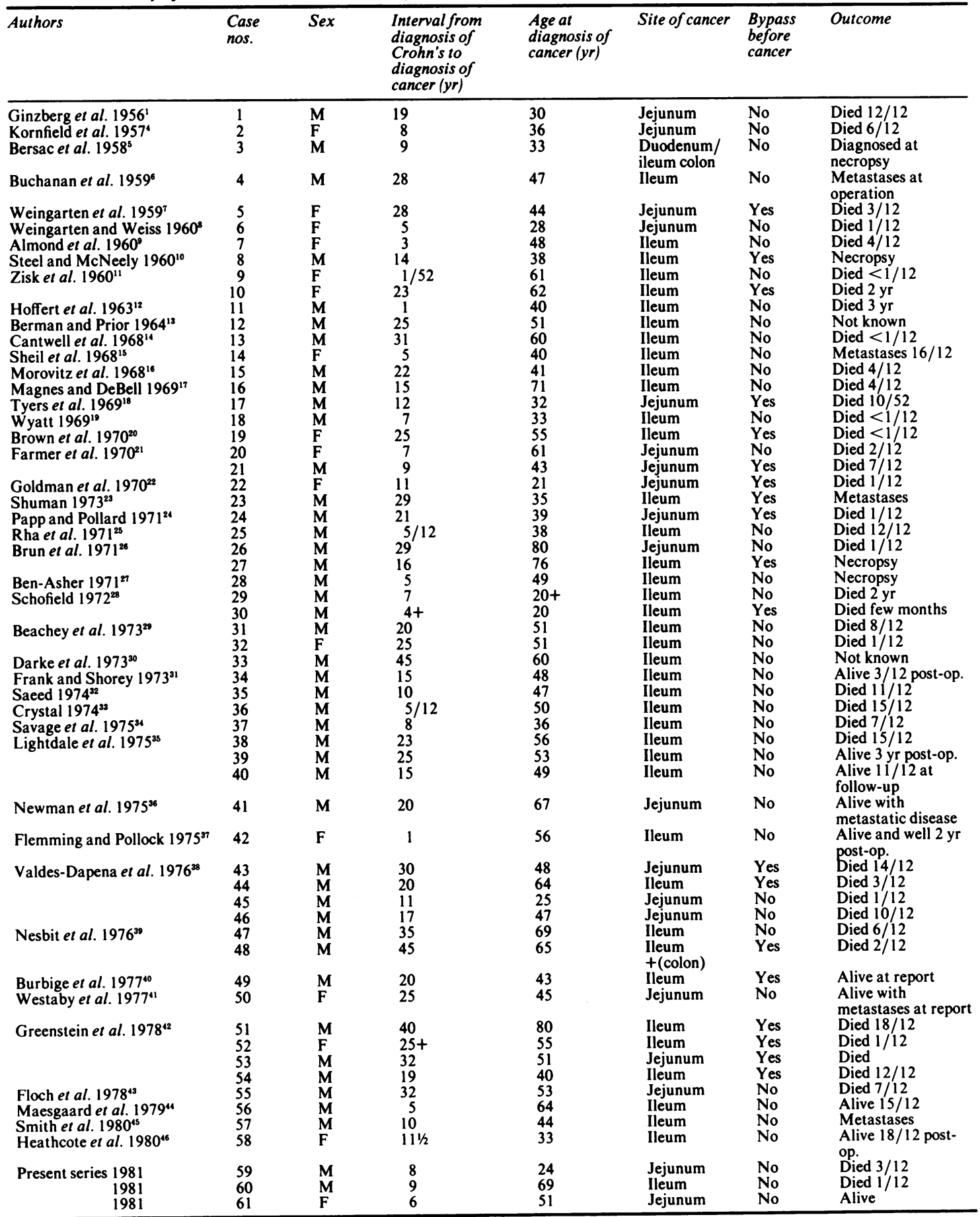




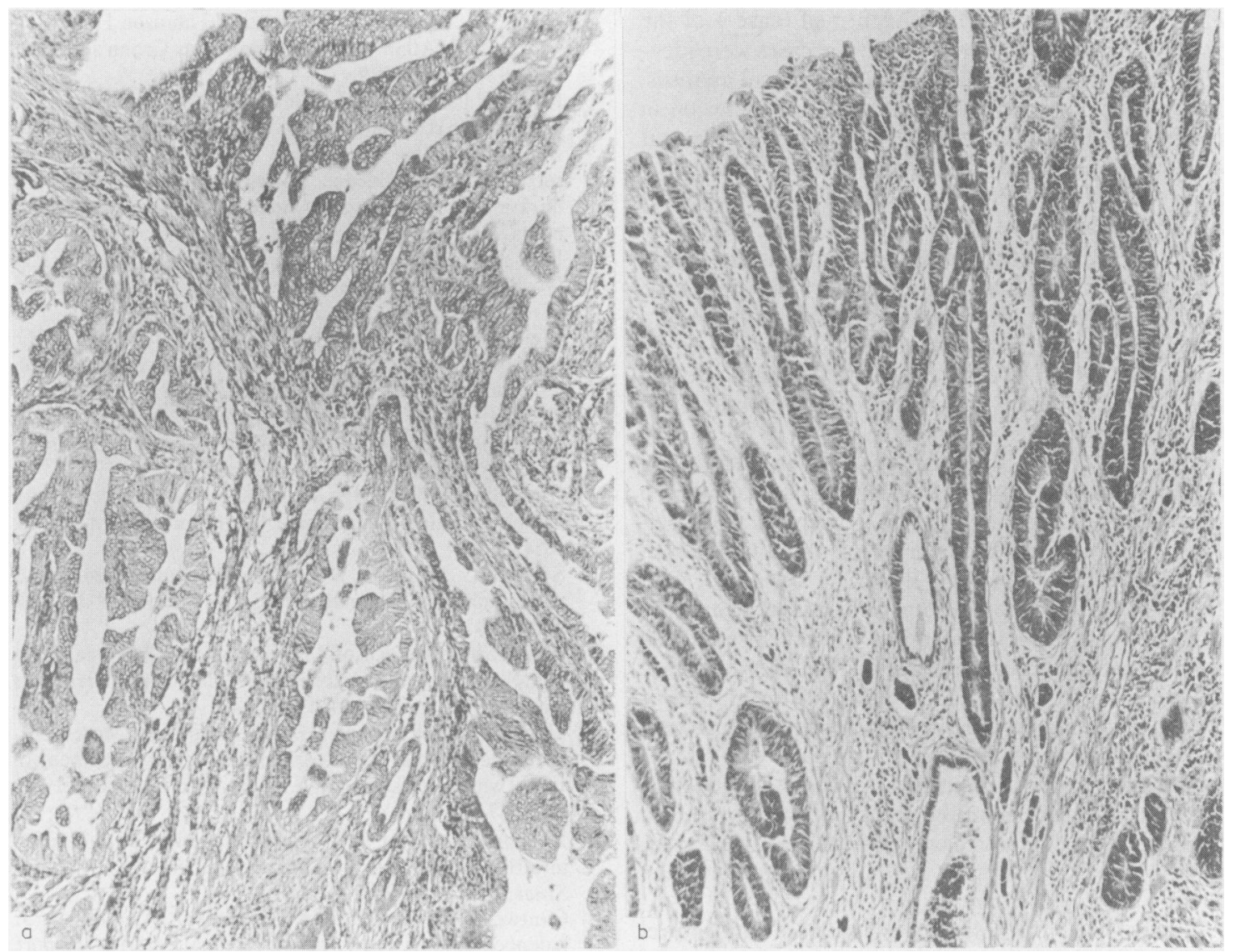

Fig. 3 Case 3. (a) Histology showing papillary adenocarcinoma. Haematoxylin and eosin. (b) Histology showing severe intestinal dysplasia. Haematoxylin and eosin.

Table 2 Data from reported cases

\begin{tabular}{|c|c|}
\hline $\begin{array}{l}\text { Total number of cases } \\
\text { Mean duration of Crohn's disease } \\
\text { Mean age at diagnosis of cancer }\end{array}$ & $\begin{array}{l}61 \text { (Male } 45, \text { Female } 16) \\
18 \cdot 2 \mathrm{yr}(1 / 52-45 \mathrm{yr}) \\
46.9 \mathrm{yr}(20-80 \mathrm{yr})\end{array}$ \\
\hline $\begin{array}{l}\text { Site of tumour } \\
\text { Jejunum } \\
\text { Ileum } \\
\text { Other }\end{array}$ & $\begin{array}{c}18(30 \%) \\
41(67 \%) \\
2(3 \%)\end{array}$ \\
\hline $\begin{array}{l}\text { Tumours in bypassed loops: } \\
\text { Jejunal } \\
\text { Ileal }\end{array}$ & $\begin{array}{r}6 \\
12\end{array}$ \\
\hline $\begin{array}{l}\text { Outcome } \\
\text { Dead } \\
\text { (Diagnosed at necropsy: 4) } \\
\text { Alive with metastatic disease } \\
\text { Alive and well without recorded } \\
\text { metastases at follow-up } \\
\text { Not known }\end{array}$ & $\begin{array}{l}44 \text { Mean survival } 7.9 \mathrm{mth} \\
(1 / 7-3 \mathrm{yr}) \\
7 \\
8 \text { Mean interval } 16 \mathrm{mth} \\
(3 / 12-3 \mathrm{yr}) \\
2\end{array}$ \\
\hline
\end{tabular}

The prognosis was poor. The mean interval between diagnosis of cancer and death was 7.9 months. No five year survivors have been reported.

\section{Discussion}

Small bowel carcinoma is a rare condition in the general population with an incidence of approximately $0 \cdot 3 / 100,000$ population/year. ${ }^{490}$ Crohn's disease is also uncommon, incidence $0 \cdot 8$ to $3 \cdot 7 / 100,000$ population/year, ${ }^{51}$ so that hospital series tend to be small in size (200-500 cases). ${ }^{2}{ }^{315}{ }^{30} 52$ It follows that, even in a large hospital series under long-term review, the number of observed cases of small bowel cancer will be insufficient to allow any definite statistical conclusions to be drawn as to the cancer risk.

In a study from this unit of 513 patients under longterm review between 1944 and $1976^{3}$ only one patient 
with small bowel cancer was identified (case 1 of the present series). The other two reported cases were identified after the closing date for the statistical analysis. They would, however, not be eligible for inclusion in any future analysis, as they first presented to the unit with cancer complicating Crohn's disease. This constitutes selection for cancer, as the symptoms of cancer were the reason for referral.

A policy of surgical resection for persistent symptoms will further reduce the apparent cancer risk in the small intestine and prevent any statistical proof of an association between Crohn's disease and small bowel cancer. Moreover, the cancers that do occur are often small and can readily be overlooked unless a detailed histological search is made.

The different distribution of small bowel cancer in Crohn's disease, however, when compared with the general population supports the concept of an association. In Crohn's disease $67 \%$ of the small bowel cancers occur in the ileum, compared with $20.5 \%{ }^{53}-30.5 \%{ }^{54}$ in the general population. The distribution of cancer of the colon in Crohn's disease also differs from the general population. In Crohn's disease the cancers are found predominantly in the right side of the colon, compared with the sigmoid colon and rectum in the general population.

Eight examples of multifocal cancers of the small intestine have been reported and dysplastic changes in the surrounding mucosa have been observed in 12 cases, lending additional support to the association between Crohn's disease and cancer.

Greenstein et al.$^{42}$ described examples of small bowel cancer occurring in bypassed loops, suggesting that the risk of developing cancer is increased if macroscopically involved segments are left in situ for many years.

The prognosis of patients with small bowel cancer in Crohn's disease is poor, possibly because most tumours are diagnosed only at a late symptomatic stage. In the published reports $72 \%$ of cases were dead (mean survival 7.9 months from diagnosis of cancer). Only 15 patients were alive with an interval since diagnosis of cancer of 16 months. No five year survivors have been reported.

The possibility of malignant change in the small intestine should be considered in those few patients with longstanding macroscopic Crohn's disease, who develop recurrent symptoms after a prolonged period without symptoms.

\section{References}

1 Ginzburg L, Schneider KM, Dreizin DH, Levinson C. Carcinoma of the jejunum occurring in a case of regional enteritis. Surgery 1956; 39:347-51.

2 Weedon DD, Shorter RG, Ilstrup DM, Huizenga KA, Taylor WF. Crohn's disease and cancer. $N$ Engl J Med 1973; 289:1099-103.
3 Gyde SN, Prior P, Macartney JC, Thomson H, Waterhouse JAH, Allan RN. Malignancy in Crohn's disease. Gut 1980; 21:1024-9.

4 Kornfeld P, Ginzburg L, Aldersberg D. Adenocarcinoma occurring in regional jejunitis. Am J Med 1957; 23:493-8.

5 Bersac SR, Howe JS, Rehac EM. A unique case with roentgenologic evidence of regional enteritis of long duration and histologic evidence of diffuse adenocarcinoma. Gastro enterology 1958; 34:703-10.

6 Buchanan DP, Heubner GD, Woolvin SC, North RL, Novak TD. Carcinoma of the ileum occurring in an area of regional enteritis. Am J Surg 1959; 97:336-9.

7 Weingarten B, Parker JG, Chazen EM, Jacobson EG. Adenocarcinoma of the jejunum in non-specific granulomatous enteritis. Arch Surg 1959; 78:483-9.

8 Weingarten B, Weiss J. Malignant degeneration in chronic inflammatory disease of the colon and small intestine. Am J Gastroenterol 1960; 33:203-7.

9 Almond CH, Neal MP, Moedl KR. Regional ileitis with coincident ileal carcinoma. Missouri Med 1960; 57:452-3.

10 Steele DC, McNeely DT. Adenocarcinoma arising in a site of chronic regional ileitis. Can Med Ass J 1960; 83:379-81.

11 Zisk J, Shore JM, Rosoff L, Friedman NB. Regional ileitis complicated by adenocarcinoma of the ileum. A report of two cases. Surgery 1960; 47:970-4.

12 Hoffert PW, Weingarten B, Friedman LD, Morecki R. Adenocarcinoma of the terminal ileum in a segment of bowel with co-existing active ileitis. N Y State J Med 1963; 63:1567-71.

13 Berman LG, Prior RT. Adenocarcinoma of the small intestine occurring in a case of regional enteritis. J Mount Sinai Hosp N Y 1964; 31:30-7.

14 Cantwell JD, Kettering RG, Carney JA, Ludwig J. Adenocarcinoma complicating regional enteritis. Report of a case and review of the literature. Gastroenterology 1968; 54:599-604.

15 Sheil F O'M, Clark CG, Goligher JC. Adenocarcinoma associated with Crohn's disease. Br J Surg 1968; 55:53-8.

16 Morovitz DA, Block GE, Kirsner JB. Adenocarcinoma of the ileum complicating chronic regional enteritis. Gastroenterology 1968; 55:397-402.

17 Magnes M, DeBell P. Carcinoma associated with terminal ileitis. Med Soc N J 1969; 66:573-4.

18 Tyers GFD, Steiger D, Dudrick SJ. Adenocarcinoma of the small intestine and other malignant tumours complicating regional enteritis. Case report and review of the literature. Ann Surg 1969; 169:510-8.

19 Wyatt AP. Regional enteritis leading to carcinoma of the small bowel. Gut 1969; 10:924-7.

20 Brown N, Weinstein VA, Janowitz HD. Carcinoma of the ileum 25 years after bypass for regional enteritis. J Mount Sinai Hosp N Y 1970; 37:675-7.

21 Farmer RO, Hawk WA, Turnbull RD. Carcinoma associated with regional enteritis. Am J Dis 1970; 15:365-71.

22 Goldman LI, Brahm SP, Cox W, Pearle AR. Adenocarcinoma of the small bowel complicating Crohn's disease. Cancer 1970; 26:1119-25.

23 Schuman BM. Adenocarcinoma arising in an excluded loop of jejunum. $N$ Engl J Med 1970; 283:136-7.

24 Papp JP, Pollard HM. Adenocarcinoma occurring in 
Crohn's disease of the small intestine. Am J Gastroenterol 1971; 56:149-56.

25 Rha CK, Klein NC, Wilson JM. Adenocarcinoma of the ileum with co-existing regional enteritis. Arch Surg 1971; 102:630-3.

26 Bruni H, Lilly J, Newman W, McHardy G. Small bowel carcinoma as a complication of regional enteritis. South Med J 1971; 64:577-80.

27 Ben-Asher $\mathbf{H}$. Adenocarcinoma of the ileum complicating regional enteritis. Am J Gastroenterol 1971; 55:391-8.

28 Schofield PF. Intestinal malignancy and Crohn's disease. Proc Roy Soc Med 1972; 65:783-4.

29 Beachley MC, Loebel A, Lankau CA, Rothman D, Boldi A. Carcinoma of the small intestine in chronic regional enteritis. Am J Dig Dis 1973; 18:1095-8.

30 Darke SG, Parks AG, Grogono JL, Pollock DJ. Adenocarcinoma in Crohn's disease. A report of two cases and analysis of the literature. Br J Surg 1973; 60:169-75.

31 Frank JD, Shorey BA. Adenocarcinoma of the small bowel as a complication of Crohn's disease. Gut 1973; 14:120-4.

32 Saeed M, Sims S, Burch BW. Development of carcinoma in regional enteritis. Arch Surg 1974; 108:376-9.

33 Crystal RD. Development of carcinoma in regional enteritis. Arch Surg 1974; 109:124.

34 Savage RA, Farmer RG, Hawk WA. Carcinoma of the small intestine associated with transmural ileitis (Crohn's disease). Am J Clin Pathol 1975; 63:168-78.

35 Lightdale CJ, Sternberg SS, Posner K, Sherlock P. Carcinoma complicating Crohn's disease. Report of seven cases and review of the literature. Am J Med 1975; 59:262-7.

36 Newman RD, Bennett SJ, Pascall RR. Adenocarcinoma of the small intestine arising in Crohn's disease. Demonstration of a tumour associated antigen in invasion and intra-epithelial components. Cancer 1975; 36:2016-9.

37 Flemming KA, Pollock AC. A case of Crohn's carcinoma. Gut 1975; 16:533-7.

38 Valdes-Dapena A, Rudolph P, Hidayat A, Roth JIA, Laucks RB. Adenocarcinoma of the small bowel in association with regional enteritis. Cancer 1976; 37:2938-47.

39 Nesbit RR, Elbadowi NA, Morton JH, Cooper RA. Car- cinoma of the small bowel. A complication of regional enteritis. Cancer 1976; 37:2948-59.

40 Burbige EJ, Bedine MS, Handelsman JC. Adenocarcinoma of the small intestine in Crohn's disease involving the small bowel. West J Med 1977; 127:43-5.

41 WestabyS, Everett WG, Dick AP. Adenocarcinoma of the small intestine in a patient treated with azathioprine. Clin Oncol 1977; 3:377-81.

42 Greenstein AH, Sacher D, Pucilio A, Kreel L, Geller S, Janowitz HD, Aufses A. Cancer in Crohn's disease after diversionary surgery. A report of seven carcinoma occurring in excluded bowel. Am J Surg 1978; 135:86-90.

43 Floch HF, Slattery LR, Hazzi CG. Carcinoma of the small intestine in regional enteritis: Presentation of a case and review of the literature. Am J Gastroenterol 1978; 70:520-7.

44 Moesgaard F, Knudsen JT, Christensen N. Adenocarcinoma of the small intestine associated with Crohn's disease. Acta Chir Scand 1979; 145:577-80.

45 Smith TR, Conradi H, Bernstein R, Greweldinger J. Adenocarcinoma arising in Crohn's disease. Report of two cases. Dis Colon Rectum 1980; 23:498-503.

46 Heathcote J, Knauer CM, Oakes D, Archibald RWR. Perforation of an adenocarcinoma of the small bowel affected by regional enteritis. Gut 1980; 21:1093-6.

47 Lear PR. Physiological basis for surgical management of regional enteritis. Surg Clinics $N$ Am 1958; 38:545-59.

48 Greenstein AJ, Sachar DB, Smith H, Janowitz HD, Aufses AH. Patterns of neoplasia in Crohn's disease and ulcerative colitis. Cancer 1980; 46:403-7.

49 Ackerman LV, Del Regato JA. Cancer diagnosis treatment and prognosis 3rd ed. St Louis: Mosby, 1962: 626.

50 Haffner JFW, Semb LS. Malignant tumours of the small intestine. Acta Chir Scand 1969; 135:543-8.

51 Mendeloff AI. The epidemiology of inflammatory bowel disease. Clin Gastroenterol 1980; 9:2 259-70.

52 Perrett AD, Truelove SC, Massarella LR. Crohn's disease and carcinoma of the colon. $\mathrm{Br}$ Med J 1968; 2:466-8.

53 Colcock BP, Adamson NE. Adenocarcinoma of the jejunum and ileum. Surg Clin North Am 1959; 39: 737-44.

54 Rochlin DB, Longmire WP Jr. Primary tumours of the small intestine. Surgery 1961; 50:586-92. 